
$\angle$ Research Square
Preprints are preliminary reports that have not undergone peer review.
They should not be considered conclusive, used to inform clinical practice,
or referenced by the media as validated information.

\title{
Familial SYN1 Pathogenic Mutations Related Neurodevelopmental Disorders in Asian Pediatric Patients
}

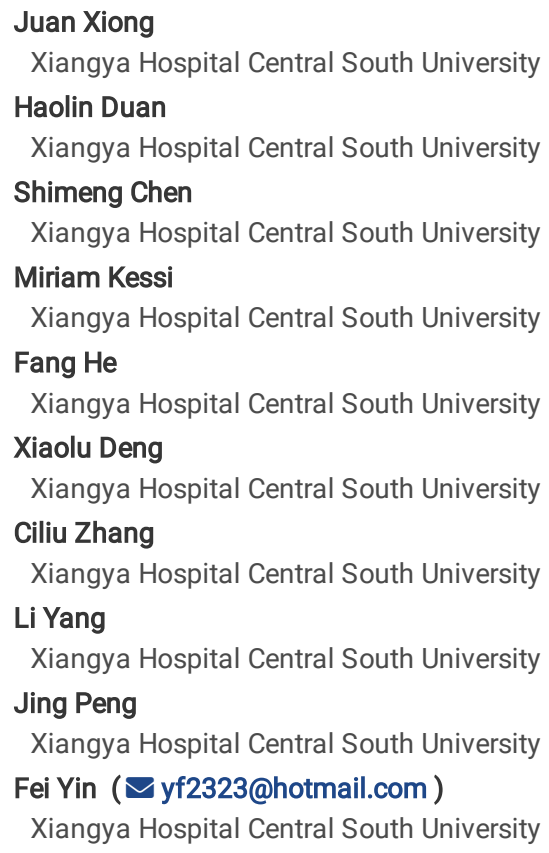

Version of Record: A version of this preprint was published at BMC Medical Genomics on July 9th, 2021. See the published version at https://doi.org/10.1186/s12920-021-01028-4. 


\begin{abstract}
Background: SYN1 encodes synapsin I, which is a neuronal phosphoprotein in relation to the membranes of small synaptic vesicles. Pathogenic variants in the gene have been confirmed as genetic causes of neurodevelopmental disorders.

Methods: In our study, we collected clinical information of two male probands with intellectual disability, and performed whole exome sequencing on both patients and their parents. We also reviewed more SYN1 variant cases in pervious publications.

Results: Two maternally inherited variants in SYN1 gene (NM_133499:c.C1076A (p.T359K) in proband A and NM_133499:c.C1444T (p. Q482X) in proband B) were found in our patients, which have never been described in detail before. After a literature review, we found that all probands have been reported so far were male, who inherited the significant SYN1 variants from their asymptomatic or mild affected mother. Although the disease encompasses three main clinical presentations: mental deficiency, easily controlled reflex seizure and behavior problems, the phenotypes of family members vary in gender.
\end{abstract}

Conclusion: Here, we firstly report two familial SYN1-related neurodevelopmental disorders in Asian pediatric patients. Our results supported that gender and phenotype differences should be highly valued in this disorder.

\title{
Background
}

The SYN1 gene is located in chromosome Xp11.23, and it encodes for Synapsin I protein which has been reported to play a crucial role in synaptogenesis, synaptic neurotransmission, axonogenesis, and neuronal development both in vivo and in vitro studies [1]. Pathogenic variants in SYN1 gene have been reported to associate with X-linked epilepsy with variable learning disabilities and behavior disorders (OMIM 300491) [2]. Like other X-linked neurodevelopmental disorders such as Turner-type X-linked syndromic mental retardation (OMIM 309590), the disease's clinical characteristics differ in gender. People most affected are males, whose clinical presentations include variable degrees of intellectual disability/global developmental delay, epilepsy, movement disorder, autistic traits, and behavior problems. Comparatively, female carriers are often asymptomatic or only exhibit mild cognitive impairment or febrile seizures [2]. Until this study, pathogenic SYN1 mutations have been reported from Europe and North America, but none from Asian population.

Here, we report two maternally inherited SYN1 mutations [c.C1076A (NM_133499) and c.C1444T (NM_133499)] detected in two male pediatric patients with intellectual disabilities and epilepsy with/without behavior disorders. This report is accompanied by a comprehensive literature review about the genotypes, phenotypes and possible mechanisms of the condition. To the best of our knowledge, this is the first report on SYN1-related neurodevelopmental disorders from Asian population.

\section{Methods \\ Subjects}

Our probands A and B were from the pedigree A and pedigree B, respectively. The probands were first referred to the Pediatric Department at Xiangya Hospital, Central South University with complaining of intellectual disability. Written informed consents for genetic testing were obtained from the pedigrees. The study was approved by the institutional medical ethics committee of Xiangya hospital, Central South Univesity.

\section{Molecular and Bioinformatic Analysis}

The G-banding technique was used to analyze the chromosomal karyotype. Genomic DNAs were collected from whole blood samples by using Phenol/chloroform method. Chromosome microarray (CMA) were used to detect chromosomes' copy number variations in both two cases. Whole-exome sequencing(WES) was performed on both pedigrees and the results were analyzed as described before [3]. Candidate variants were validated by Sanger sequencing. Variant impact predictor software including PolyPhen2 (http://genetics.bwh.harvard.edu/pph2/), PROVEAN (http://provean.jcvi.org/), Mutation Taster (http://www.mutationtaster.org/), and the ACMG guidelines were adopted to analyze the pathogenicity of the variants [4].

\section{Results \\ Clinical information}

\section{Proband $\mathrm{A}$ and Pedigree $\mathrm{A}$}

The patient was a 6 years and 3 months old boy, who was born in a non-consanguineous family. He was the first child of a mother with histories of obstetric complications including one induced abortion due to side effects of antifungal medication and a spontaneous abortion of unknown cause. In addition, the mother had an early threatened miscarriage during the pregnancy of probands A, but she got a remission after immediate medical intervention. The case was delivered at full-term via caesarian section. The physical examination was unremarkable at birth.

The first noticeable clinical characteristic of this case was a profound global developmental delay which was noted since his infancy. His gross and fine motor skills were acquired and improved slowly: neck muscle control was achieved at the age of 15 months, sit with support at the age of 4 years, walk dependently, and inflexible finger movements at the last follow up ( 6 years and 3 months). Besides, he had a cognitive impairment and difficulties in language acquisition. At the last follow up, he only could understand some simple terms such as his nickname or some simple instructions, but could not speak a word. There has

Page 2/8 
been no aggressive behavior noticed in proband A so far. Moreover, his daily life needed to be fully taken care of by others. Complex febrile seizures were observed in the course: one episode occured at the age of 1 year and the second one at the age of 2 years. he electroencephalogram (EEG) and magnetic resonance imaging (MRI) of the brain done at 4 years old age were normal. Meanwhile, the development quotients for adaptability, gross motor movements, fine motor movements, language, and individual-social interaction on the Gesell developmental scales were $36,41,30,43$, and 50, respectively. Other laboratory examinations including the routine blood biochemical tests, metabolic analyses yielded negative. He had a medical history of bilateral esotropia.

This case had a healthy younger brother whose age was two years old at the last follow up (Fig. 1a). His mother had no neurological signs. Noticeably, epileptic seizures were also observed in his biological father's childhood, which began with febrile seizures, then evolved to afebrile attacks. But his symptoms disappeared in adulthood. There was no other family history of neurological disorders to disclose.

\section{Proband B and Pedigree B}

An 8.5-year-old boy presenting with intellectual disability, epilepsy, abnormal social behavior, and ametropia came to our center's clinic. The patient was born as a third child of non-consanguineous healthy parents after uneventful pregnancy and delivery. A distant uncle of the proband was diagnosed with intellectual disability, and his older female cousin was noticed to have a mood disorder.

The first remarkable seizure was observed when aged 7 years. The manifestations of the seizures included the sudden loss of consciousness, rigidity of the limbs, and lips cyanosis, which lasted for minutes. Besides, he had post-ictal fatigue, and experienced 1-3 seizure episodes per year. His EEG revealed occasional sharp-waves were observed in bilateral frontal areas during sleep, but absent during the wake time. Brain MRI did not reveal significant structural abnormalities. His seizure was easily controlled by taking Levetiracetam, but he still lagged behind his peers in intelligence development (he had poor performance in school and could not communicate well with others). His intelligence quotient score at 8.5-year-old was 50.9. He also exhibited bad tempers, social problems, attention deficit, and hyperactivity. Nevertheless, the behavior assessments, including Conners' Comprehensive Behavior Rating Scales (CBRS), Kiddie-SADS DSM-5 Screen Interview (K-SADS-PL), and Autism Behavior Checklist (ABC) were negative. In addition, the proband was diagnosed with ametropia. Metabolic etiology, immunological etiology, and infectious etiology were excluded after the diagnostic workup.

The proband had two healthy elder sisters, 18 and 14 years old, respectively. They both performed well in school (Fig. 1b). His parents had low levels of education but worked, and thus they can support their family well.

\section{Genetic findings}

The karyotype and copy number variation results in probands A and B showed no abnormalities in their chromosomes. Maternal inherited SYN1 mutations were identified in both probands through the WES.

In the pedigree A, a missense variant in SYN1 exon 9: c.C1076A, p.T359K (NM_133499) was present in a hemizygous state in proband A and a heterozygous state in his mother, grandmother, and great-grandmother as an obligate carrier, but it was absent in his younger brother, father, and grandfather (Fig. 1 a \& Fig.

1c). The variant T359K has been reported as a variant of uncertain significance in ClinVar database records (accession VCV000589101.2), associated with a "history of neurodevelopmental disorder" [5]. However, no more detail clinical information of the patient was described in the database. The substitution of lysine for threonine acid at position 359 within domain C of SYN1 protein is considered "possibly damaging" (score 0.886 ) with PolyPhen2 (http://genetics.bwh.harvard.edu/pph2/), "deleterious" (score -2.565) with PROVEAN (http://provean.jcvi.org/) and "disease-causing" (score 78) with MutationTaster (http://www.mutationtaster.org/).

In the pedigree B, a truncation variant in SYN1 exon 12: c.C1444T, p.Q482X (NM_133499) was identified, which was also present in a hemizygous state in proband $B$, and a heterozygous state in his mother but it was absent in his father (Fig. 1d). The variant validation of other family members was not done for financial reasons (Fig. 1b). The variant has never been reported before and cannot be found in dbSNP143, the 1000 Genomes Project database, and the Clinvar database. The nonsense mutation Q482X lies in the domain D of the protein and is identified as "disease-causing" (score 6) with MutationTaster (http://www.mutationtaster.org/).

Bioinformatic analysis showed that sites T359 and Q482 are highly conserved residues among different species (Fig. 1e). Both variants were classified as "Pathogenic," according to the ACMG guidelines ${ }^{4}$.

\section{Discussion}

The SYN1 gene encodes Synapsin-I and is essential for proper synaptic function in the human brain [6]. Since Garcia CC et al. firstly connected SYN1 mutation with neurodevelopmental disorder in 2004, 16 causative variants including ten missense mutations, five nonsense mutations, and one splicing site mutation in the gene have been identified (containing this study) (Fig. 2) [1,2,7-16]. These variants are clustered in B linker domain (A51G, S79W), actin-binding and synaptic-vesicle binding C-domain (W126X, W126R, c.527+1G>A, S212I, G240R, V266M, W356X, T359K, R420G) and proline-rich D-domain (R422X, Q482X, A550T, Q555X, T567A) of the encoded protein as indicated (Fig. 2). There is no reported variant situated in the other two domains (A and E) until now (including this report). We assumed that defects in the middle motifs of Synapsin I are inclined to lead to neurodevelopmental disorders in human after birth. Domain A is highly conserved across all synapsins and species [6], and domain E plays a critical role in Synapsin I functions, including the formation of synaptic vesicle (SV) reserve pool, regulation of the kinetics of exocytosis, and SV cycling [6,17]. Thus, we speculate that the defects in domain A and E might be extremely deleterious for the intrauterine development of human beings. Notably, all reported pathogenic variants in the literature plus ours were confirmed as inheriting from the maternal side. 
To better understand the clinical characteristics of SYN1-related disorder, we conducted a literature review of all reported pedigrees from the Pubmed and Embase on English articles. Clinical information of 7 pedigrees with the disorder from 7 studies was collected in the report (Table 1) [2,9-14], and other cases were excluded for lack of detail descriptions $[1,7,8,15,16]$. Overall, we noticed that females are less susceptible than males due to X-chromosome random inactivation $(\mathrm{XCl})$, however, few female carriers presented with mild intellectual disability and febrile seizures [8,14]. Besides, the phenotypic differences occurred not only in different pedigrees but also in the same pedigree. Unfortunately, we cannot draw a conclusion whether there is any difference among races as the sample size was too small. But some similar clinical features were found among these patients.

Table 1

Clinical and genetic characteristics of patients with SYN1-related disorders in literature and the study

\begin{tabular}{|c|c|c|c|c|c|c|c|c|c|}
\hline Reference & $\begin{array}{l}\text { Garcia CC, } \\
\text { et al. } 2004^{2}\end{array}$ & $\begin{array}{l}\text { Nguyen DK, } \\
\text { et al. } 2015^{9}\end{array}$ & $\begin{array}{l}\text { Sirsi D, } \\
\text { et al. 2017* } \\
10\end{array}$ & $\begin{array}{l}\text { Guarnieri FC, } \\
\text { et al. } 2017^{14}\end{array}$ & $\begin{array}{l}\text { Peron A, } \\
\text { et al. } 2018^{13}\end{array}$ & $\begin{array}{l}\text { Darvish H, } \\
\text { et al. } 202012\end{array}$ & $\begin{array}{l}\text { Ibarluzea N, } \\
\text { et al. } 2020^{11}\end{array}$ & $\begin{array}{l}\text { Pedigree A } \\
\text { (this study) }\end{array}$ & $\begin{array}{l}\text { Pedigr } \\
\text { (this S' }\end{array}$ \\
\hline $\begin{array}{l}\text { Country } \\
\text { (ethnic) }\end{array}$ & $\begin{array}{l}\text { England } \\
\text { (unknown) }\end{array}$ & $\begin{array}{l}\text { Canada } \\
\text { (French- } \\
\text { Canadian) }\end{array}$ & $\begin{array}{l}\text { America } \\
\text { (Latino) }\end{array}$ & $\begin{array}{l}\text { Italy } \\
\text { (unknown) }\end{array}$ & $\begin{array}{l}\text { Italy } \\
\text { (unknown) }\end{array}$ & $\begin{array}{l}\text { America } \\
\text { (unknown) }\end{array}$ & $\begin{array}{l}\text { Spain } \\
\text { (unknown) }\end{array}$ & $\begin{array}{l}\text { China } \\
\text { (Han) }\end{array}$ & $\begin{array}{l}\text { China } \\
\text { (Han) }\end{array}$ \\
\hline \multicolumn{10}{|l|}{$\begin{array}{l}\text { Basic } \\
\text { information }\end{array}$} \\
\hline $\begin{array}{l}\text { Sex of } \\
\text { probands }\end{array}$ & $\begin{array}{l}\text { Male } \\
\text { (assumed) }\end{array}$ & Male & Male & Unknown & Male & Male & Male & Male & Male \\
\hline $\begin{array}{l}\text { Affected } \\
\text { family } \\
\text { members }\end{array}$ & Male (10) & $\begin{array}{l}\text { Male (10); } \\
\text { Female (2) }\end{array}$ & - & $\begin{array}{l}\text { Male (8); } \\
\text { Female (2) }\end{array}$ & Male (2) & Male (3) & Male (2) & Male (1) & Male ( \\
\hline $\begin{array}{l}\text { Carrier } \\
\text { family } \\
\text { members }\end{array}$ & Female (9) & Female (8) & Female (1) & Female (1) & Female (1) & Unknown & Female (5) & Female (3) & Femal \\
\hline $\begin{array}{l}\text { SYN1 } \\
\text { variants }\end{array}$ & $\begin{array}{l}\text { c.G1068A } \\
\text { (p.W356X) } \\
\text { [NM_133399] }\end{array}$ & $\begin{array}{l}\text { c.C1663T } \\
\text { (p.Q555X) } \\
\text { [NM_133399] }\end{array}$ & $\begin{array}{l}\text { c.C1264T } \\
\text { (p.R422X) } \\
\text { [NM_133399] }\end{array}$ & $\begin{array}{l}\text { c.C236G } \\
\text { (p.S79W) } \\
\text { [NM_133399] }\end{array}$ & $\begin{array}{l}\text { c.527+1G>T } \\
\text { [NM_133399] }\end{array}$ & $\begin{array}{l}\text { c.G1259A } \\
\text { (p. R420Q) } \\
\text { [NM_133399] }\end{array}$ & $\begin{array}{l}\text { c.G796A } \\
\text { (p.V266M) } \\
\text { [NM_133399] }\end{array}$ & $\begin{array}{l}\text { c.C1076A } \\
\text { (p.T359K) } \\
\text { [NM_133399] }\end{array}$ & $\begin{array}{l}\text { c.C144 } \\
\text { (p.Q4E } \\
\text { [NM_1 }\end{array}$ \\
\hline Diagnosis & $\begin{array}{l}\text { Variable } \\
\text { epilepsy, } \\
\text { learning } \\
\text { disabilities, } \\
\text { and } \\
\text { aggressive } \\
\text { behavior }\end{array}$ & $\begin{array}{l}\text { X-linked } \\
\text { focal } \\
\text { epilepsy with } \\
\text { reflex related- } \\
\text { bathing } \\
\text { seizures }\end{array}$ & $\begin{array}{l}\text { Focal } \\
\text { epilepsy and } \\
\text { reflex related- } \\
\text { bathing } \\
\text { seizures, } \\
\text { autism, and } \\
\text { intellectual } \\
\text { disability }\end{array}$ & $\begin{array}{l}\text { Non- } \\
\text { syndromic } \\
\text { intellectual } \\
\text { disability }\end{array}$ & $\begin{array}{l}\text { Hot water- } \\
\text { sensitive } \\
\text { epilepsy }\end{array}$ & $\begin{array}{l}\text { Autism and } \\
\text { progressive } \\
\text { intellectual } \\
\text { disability } \\
\text { without } \\
\text { epilepsy }\end{array}$ & $\begin{array}{l}\text { Intellectual } \\
\text { disability and } \\
\text { paranoid } \\
\text { schizophrenia }\end{array}$ & $\begin{array}{l}\text { Intellectual } \\
\text { disability } \\
\text { and } \\
\text { complex } \\
\text { febrile } \\
\text { seizures }\end{array}$ & $\begin{array}{l}\text { Epilep: } \\
\text { behav } \\
\text { disord } \\
\text { and } \\
\text { learnir } \\
\text { disabi }\end{array}$ \\
\hline
\end{tabular}

Table 1

continued

\begin{tabular}{|c|c|c|c|c|c|c|c|c|c|}
\hline Reference & $\begin{array}{l}\text { Garcia CC, } \\
\text { et al. } 2004^{2}\end{array}$ & $\begin{array}{l}\text { Nguyen DK, } \\
\text { et al. } 2015^{9}\end{array}$ & $\begin{array}{l}\text { Sirsi D, } \\
\text { et al. 2017* } \\
10\end{array}$ & $\begin{array}{l}\text { Guarnieri } \\
\text { FC, et al. } \\
2017^{14}\end{array}$ & $\begin{array}{l}\text { Peron A, } \\
\text { et al. } 2018^{13}\end{array}$ & $\begin{array}{l}\text { Darvish H, } \\
\text { et al. } \\
2020^{12}\end{array}$ & $\begin{array}{l}\text { lbarluzea } \\
\text { N, et al. } \\
2020^{11}\end{array}$ & $\begin{array}{l}\text { Pedigree } \\
\text { A (this } \\
\text { study) }\end{array}$ & $\begin{array}{l}\text { Pedigree } \\
\text { B (this } \\
\text { study) }\end{array}$ \\
\hline \multicolumn{10}{|l|}{$\begin{array}{l}\text { Clinical } \\
\text { features }\end{array}$} \\
\hline $\begin{array}{l}\text { Degree of } \\
\text { intellectual } \\
\text { disability }\end{array}$ & $\begin{array}{l}\text { Normal or } \\
\text { mild }\end{array}$ & Normal or mild & - & $\begin{array}{l}\text { Moderate } \\
\text { to severe }\end{array}$ & Normal or mild & $\begin{array}{l}\text { ID from } \\
\text { early } \\
\text { childhood } \\
\text { mental } \\
\text { regression }\end{array}$ & Mild & Profound & Moderate \\
\hline $\begin{array}{l}\text { Presence } \\
\text { of epilepsy }\end{array}$ & Y & Y & Y & $\mathrm{N}$ & $Y$ & $\mathrm{~N}$ & $\mathrm{~N}$ & $\mathrm{Y}$ & Y \\
\hline $\begin{array}{l}\text { Onset age } \\
\text { of seizures }\end{array}$ & $6-27 y$ & $1 y 8 m-50 y$ & $\begin{array}{l}\text { Early } \\
\text { childhood }\end{array}$ & - & $8 y$ & - & - & $1 y$ & $7 y$ \\
\hline $\begin{array}{l}\text { Seizure } \\
\text { semiology }\end{array}$ & $\begin{array}{l}\text { Tonic-clonic, } \\
\text { reflex, and } \\
\text { partial and } \\
\text { complex- } \\
\text { partial } \\
\text { seizures }\end{array}$ & $\begin{array}{l}\text { Spontaneous } \\
\text { complex partial } \\
\text { seizures and } \\
\text { reflex seizures } \\
\text { triggered by } \\
\text { bathing }\end{array}$ & $\begin{array}{l}\text { Focal } \\
\text { seizures and } \\
\text { reflex } \\
\text { seizures } \\
\text { triggered by } \\
\text { bathing }\end{array}$ & - & $\begin{array}{l}\text { Hot water sensitive } \\
\text { seizures at the } \\
\text { beginning, } \\
\text { subsequently } \\
\text { followed by } \\
\text { nonreflex seizures }\end{array}$ & - & - & $\begin{array}{l}\text { Tonic- } \\
\text { clonic } \\
\text { seizures } \\
\text { triggered } \\
\text { by fever }\end{array}$ & $\begin{array}{l}\text { Tonic- } \\
\text { clonic } \\
\text { seizures }\end{array}$ \\
\hline $\begin{array}{l}\text { Seizure } \\
\text { frequency }\end{array}$ & Episodic & Episodic & $\begin{array}{l}1-2 \text { times } \\
\text { per month }\end{array}$ & - & Unknown & - & - & $\begin{array}{l}\text { Only } 2 \\
\text { times }\end{array}$ & Episodic \\
\hline
\end{tabular}


Table 1

continued

\begin{tabular}{|c|c|c|c|c|c|c|c|c|c|}
\hline Reference & $\begin{array}{l}\text { Garcia CC, } \\
\text { et al. } 2004^{2}\end{array}$ & $\begin{array}{l}\text { Nguyen DK, } \\
\text { et al. } 2015^{9}\end{array}$ & $\begin{array}{l}\text { Sirsi D, } \\
\text { et al. } 2017 * \\
10\end{array}$ & $\begin{array}{l}\text { Guarnieri } \\
\text { FC, et al. } \\
2017^{14}\end{array}$ & $\begin{array}{l}\text { Peron A, } \\
\text { et al. } 2018^{13}\end{array}$ & $\begin{array}{l}\text { Darvish H, } \\
\text { et al. } 2020 \\
12\end{array}$ & $\begin{array}{l}\text { Ibarluzea } \\
\text { N, et al. } \\
2020^{11}\end{array}$ & $\begin{array}{l}\text { Pedigree } \\
\text { A (this } \\
\text { study) }\end{array}$ & $\begin{array}{l}\text { Pedigree B } \\
\text { (this } \\
\text { study) }\end{array}$ \\
\hline $\begin{array}{l}\text { Seizure } \\
\text { control or } \\
\text { not }\end{array}$ & $\mathrm{Y}$ & $\begin{array}{l}\text { Most affected } \\
\text { members } \\
\text { have } \\
\text { achieved } \\
\text { seizure } \\
\text { control }\end{array}$ & $\begin{array}{l}\text { Intractable to } \\
\text { AEDs, } \\
\text { seizures } \\
\text { reduce about } \\
50 \% \text { by VNS. }\end{array}$ & - & Unknown & - & - & Y & $\mathrm{Y}$ \\
\hline \multicolumn{10}{|l|}{$\begin{array}{l}\text { Abnormal } \\
\text { behavior }\end{array}$} \\
\hline Aggression & $\mathrm{Y}$ & $\mathrm{N}$ & $\mathrm{N}$ & - & $\mathrm{N}$ & $\mathrm{N}$ & $\mathrm{N}$ & $\mathrm{N}$ & $\mathrm{Y}$ \\
\hline $\begin{array}{l}\text { Autistic } \\
\text { traits }\end{array}$ & $Y$ & $\mathrm{Y}$ & $\mathrm{Y}$ & - & $\mathrm{N}$ & $Y$ & $\mathrm{Y}$ & $\mathrm{N}$ & $\mathrm{N}$ \\
\hline $\begin{array}{l}\text { EEG } \\
\text { findings }\end{array}$ & $\begin{array}{l}\text { Some evidence } \\
\text { of spikes in the } \\
\text { left temporal } \\
\text { region or } \\
\text { normal }\end{array}$ & $\begin{array}{l}\text { Rhythmic } \\
\text { theta activity } \\
\text { over temporal } \\
\text { head regions }\end{array}$ & $\begin{array}{l}\text { Spikes on the } \\
\text { left temporal } \\
\text { region }\end{array}$ & - & $\begin{array}{l}\text { Bilateral } \\
\text { rhythmic theta } \\
\text { activity over the } \\
\text { frontocentral and } \\
\text { vertex regions }\end{array}$ & - & - & Normal & $\begin{array}{l}\text { Occasional } \\
\text { sharp- } \\
\text { waves } \\
\text { occurring } \\
\text { in bilateral } \\
\text { frontal } \\
\text { areas } \\
\text { during } \\
\text { sleep }\end{array}$ \\
\hline $\begin{array}{l}\text { Brian MRI } \\
\text { imaging }\end{array}$ & Normal & $\begin{array}{l}\text { Hippocampal } \\
\text { atrophy }\end{array}$ & Normal & - & - & $\begin{array}{l}\text { Marked } \\
\text { generalized } \\
\text { frontal } \\
\text { atrophy }\end{array}$ & - & Normal & Normal \\
\hline $\begin{array}{l}\text { Other } \\
\text { findings }\end{array}$ & Macrocephaly & $\mathrm{N}$ & $\mathrm{N}$ & $\mathrm{N}$ & $\mathrm{N}$ & $\begin{array}{l}\text { Sphincter } \\
\text { dysfunction }\end{array}$ & $\mathrm{N}$ & $\begin{array}{l}\text { Bilateral } \\
\text { esotropia }\end{array}$ & Ametropia \\
\hline \multicolumn{10}{|c|}{ *The pedigree in the study has a maternal family history of epilepsy but lacks familial genetic results due to financial reasons. } \\
\hline
\end{tabular}

Firstly, cases with SYN1-related disorders presented with variable degrees of intellectual disabilities. Normal or mild cognitive impairments were reported in $5 / 9$ pedigrees, moderate to severe global developmental delay in 3/9 pedigrees, and mental regression in 1/9 pedigree (Table 1). Cases in 6/9 pedigrees were diagnosed with epilepsy, and the reflex seizure was one remarkable clinical manifestation of the disease. Noteworthy, bathing or showering was the trigger of their epileptic seizures $[9,13]$. Our cases had no history of reflex seizure, however, proband A was diagnosed as complex febrile seizures. Most of the cases presented with mild form of seizures which responded well to antiepileptic drugs. Behavioral problems such as aggression, hyperactivity, and autistic traits were the third typical clinical characteristic of the disorder. Proband B in the study had apparent aggressive behavior and attention-deficit even though the behavioral assessment scales turned out to be negative. He also presented with learning disabilities, which is similar to previously reported cases [2,13]. Patients with the above three significant clinical symptoms should alert physicians to the possibility of SYN1-related neurodevelopmental disorder. Detailed family history inquiry would also be helpful in the diagnosis.

We also noticed that both of our cases had eye problems including ametropia and strabismus, which has not been mentioned in other studies. According to the Human protein atlas database, the SYN1 RNA has low expression in the human eye, nevertheless, there is no further evidence to support the involvement of SYN1 protein in eye development [18]. Therefore, we assume that eye disorder might be a new clue for clinicians to identify the condition, however, it needs more data.

Several functional analyses have been done in recent studies to elucidate the possible mechanisms involved in SYN1-related disorder [1,12,14]. Compared to human SYN1 wildtype, expression of human SYN1 mutants such as S79W, A550T, T567A in synapsin-I (Synl) knockout (KO) mouse neurons failed to rescue aberrant size and trafficking of synaptic vesicle pools and led to defective nerve terminal function [1,14]. R420Q variant expression in human primary hippocampal neurons significantly reduced neurite outgrowth and development [12]. These findings implicate that SYN1 mutations detected in neurodevelopmental disorders lead to loss-of-function of Synapsin-I protein in the brain network, suggesting that patients with the disease might benefit from the augmentation of the protein function.

\section{Conclusions}


In conclusion, this is the first study about SYN1-related neurodevelopmental disorder in the Asian population, which expands the genetic spectrum of the disease. Remarkably, all reported significant SYN1 variants were maternally inherited, and located in middle domains of the gene. Gender differences and phenotype variances should be considered in the disorder. Besides mental deficiency, reflex seizures and behavior problems, eye disorders might be helpful to identify the condition. Combining with previous studies, loss-of-function of Synapsin-I protein is the possible mechanism in patients with the disorder.

\section{Abbreviations}

SYN1: Synapsin I; OMIM: Online mendelian inheritance in man; CMA: Chromosome microarray; WES: Whole-exome sequencing; EEG: Electroencephalogram; MRI: Magnetic resonance imaging; CBRS: Conners' Comprehensive Behavior Rating Scales; K-SADS-PL: Kiddie-SADS DSM-5 Screen Interview, ABC: Autism Behavior Checklist; SV: Synaptic vesicle; XCl: X-chromosome random inactivation; RNA: Ribonucleic acid; KO: Knockout;

\section{Declarations}

\section{Ethics approval and consent to participate}

The study adhered to the tenets of the Declaration of Helsinki and had received approval from the Institutional Review Board and Research Ethics Committee of Xiangya Hospital, Central South University, Changsha, Hunan. Written, informed consent was obtained from all participants before their inclusion in this study. We obtained written informed consent from the parents of the participant under the age of 16.

\section{Consent for publication}

Written informed consents for publication of clinical details and clinical images were obtained from participants and the parents of the participant under the age of 16 .

\section{Availability of data and materials}

All data supporting our results can be found in a published article. Current data on patients cannot be fully accessible in accordance with local research ethics protocols. However, if you are interested in this article, it may be avail- able from the corresponding author.

\section{Competing interests}

The authors claim that they have no conflict of interest.

\section{Funding}

This work was supported by the National Key Research and Development Program of China [NO.2016YFC1306202], the National Natural Science Foundation of China [N0.81771408], and the Graduate Innovation Program of Central South University [NO.2019zzts338].

\section{Authors' contributions}

Conception of the study: FY, JX. Experimental design: Study designation: JX, JP and XLD. Patient's evaluation: HLD, SMC and CLZ. Experiments: JX, SMC. Data acquisition and analysis: JX, HLD, SMC, and FH. First version of the manuscript: JX and FY. Revised version of the manuscript: JX, MK, LY, and FY. All authors read and approved the final version of the manuscript.

\section{Acknowledgements}

We would like to express our gratitude to the patients and families for participating in this study.

\section{References}

1. Fassio A, Patry L, Congia S, Onofri F, Piton A, Gauthier J, et al. SYN1 loss-of-function mutations in autism and partial epilepsy cause impaired synaptic function. Hum Mol Genet. 2011;20(12):2297-307.

2. Garcia CC, Blair HJ, Seager M, Coulthard A, Tennant S, Buddles M, et al. Identification of a mutation in synapsin I, a synaptic vesicle protein, in a family with epilepsy. J Med Genet. 2004;41(3):183-6. https://doi.org/10.1136/jmg.2003.013680.

3. Peng J, Wang Y, He F, Chen C, Wu LW, Yang LF, et al. Novel West syndrome candidate genes in a Chinese cohort. CNS Neurosci Ther. 2018; 24(12):1196206.

4. Richards S, Aziz N, Bale S, Bick D, Das S, Gastier-Foster J, et al. Standards and guidelines for the interpretation of sequence variants: A joint consensus recommendation of the American College of Medical Genetics and Genomics and the Association for Molecular Pathology. Genet Med. 2015;17(5):40524. 
5. National Center for Biotechnology Information. ClinVar; [VCV000589101.2] https://www.ncbi.nlm.nih.gov/clinvar/variation/589101/. (aceess by January $6,2021)$

6. Cesca F, Baldelli P, Valtorta F, Benfenati F. The synapsins: Key actors of synapse function and plasticity. Prog Neurobiol. 2010;91(4):313-48.

7. Rossi M, El-Khechen D, Black MH, Farwell Hagman KD, Tang S, Powis Z. Outcomes of Diagnostic Exome Sequencing in Patients With Diagnosed or Suspected Autism Spectrum Disorders. Pediatr Neurol. 2017;70:34-43.e2.

8. Butler KM, da Silva C, Alexander JJ, Hegde M, Escayg A. Diagnostic Yield From 339 Epilepsy Patients Screened on a Clinical Gene Panel. Pediatr Neurol. 2017;77:61-6.

9. Nguyen DK, Rouleau I, Sénéchal G, Ansaldo Al, Gravel M, Benfenati F, et al. X-linked focal epilepsy with reflex bathing seizures: Characterization of a distinct epileptic syndrome. Epilepsia. 2015;56(7):1098-108.

10. Sirsi D, Armstrong D, Muñoz-Bibiloni J, Redondo B, Park J. SYN1 Gene Mutation in a Child with Focal Epilepsy and Reflex Bathing Seizures. J Pediatr Epilepsy. 2017;06(02):119-24.

11. Ibarluzea N, de la Hoz AB, Villate O, Llano I, Ocio I, Martí I, et al. Targeted next-generation sequencing in patients with suggestive X-linked intellectual disability. Genes (Basel). 2020;11(1):1-22.

12. Darvish H, Azcona LJ, Tafakhori A, Mesias R, Ahmadifard A, Sanchez E, et al. Phenotypic and genotypic characterization of families with complex intellectual disability identified pathogenic genetic variations in known and novel disease genes. Sci Rep. 2020;10(1):1-12.

13. Peron A, Baratang NV, Canevini MP, Campeau PM, Vignoli A. Hot water epilepsy and SYN1 variants. Epilepsia. 2018; 59(11):2162-2163.

14. Guarnieri FC, Pozzi D, Raimondi A, Fesce R, Valente MM, Delvecchio VS, et al. A novel SYN1 missense mutation in non-syndromic X-linked intellectual disability affects synaptic vesicle life cycle, clustering and mobility. Hum Mol Genet. 2017;26(23):4699-714.

15. Fernández-Marmiesse A, Roca I, Díaz-Flores F, Cantarín V, Pérez-Poyato MS, Fontalba A, et al. Rare Variants in 48 Genes Account for $42 \%$ of Cases of Epilepsy With or Without Neurodevelopmental Delay in 246 Pediatric Patients. Front Neurosci. 2019;13:1-17.

16. Lindy AS, Stosser MB, Butler E, Downtain-Pickersgill C, Shanmugham A, Retterer K, et al. Diagnostic outcomes for genetic testing of 70 genes in 8565 patients with epilepsy and neurodevelopmental disorders. Epilepsia. 2018;59(5):1062-71.

17. Monaldi I, Vassalli M, Bachi A, Giovedi S, Millo E, Valtorta F, et al. The highly conserved synapsin domain E mediates synapsin dimerization and phospholipid vesicle clustering. Biochem J. 2010;426(1):55-64.

18. The Human Protein Altas. https://www.proteinatlas.org/ENSG00000008056-SYN1/celltype\#top. (aceess by January 6, 2021)

\section{Figures}




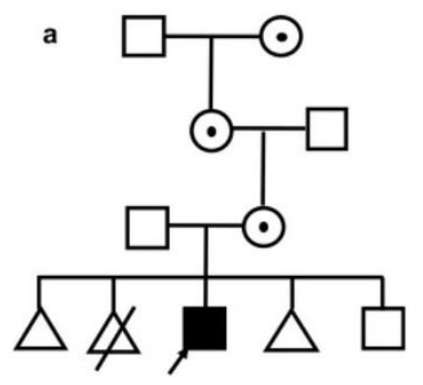

b
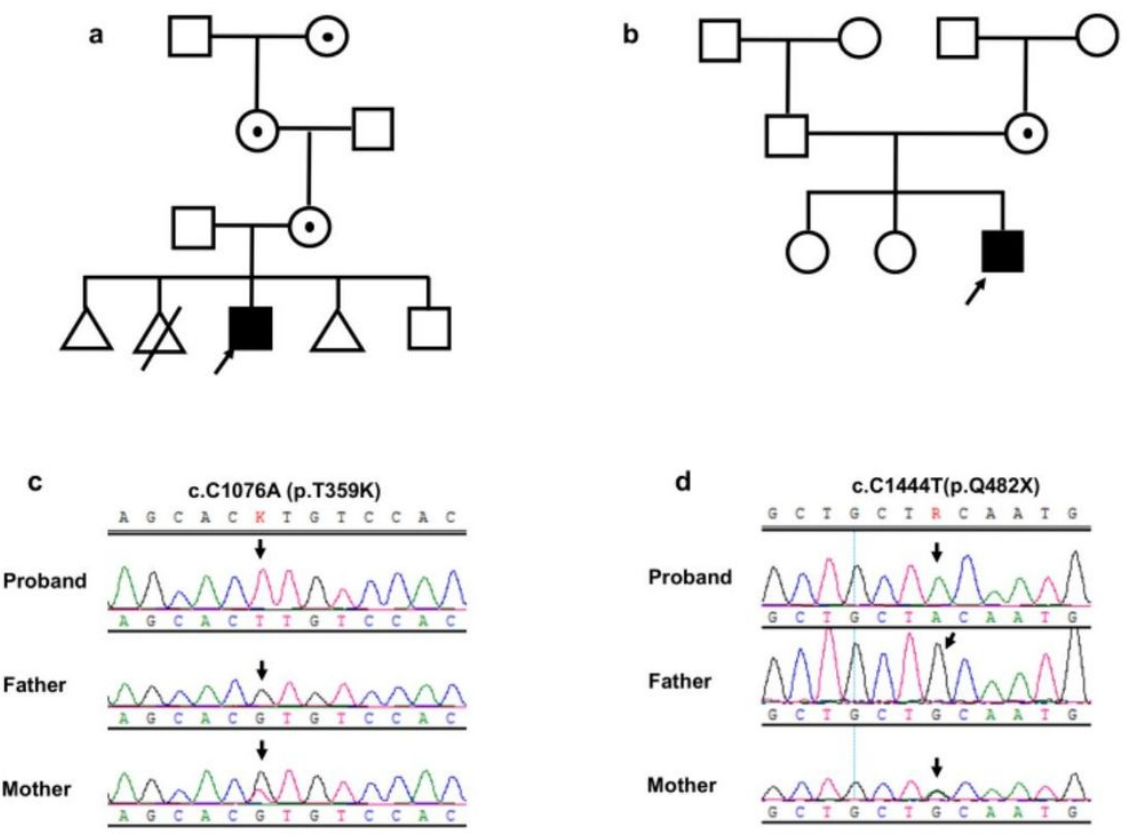

e

H. sapiens

M. musculus

B. Taurus

C. Lupus

R. norvegicus
T359

MSDRYKLWVDTCSEIFGGLDI MSDRYKLWVDTCSEIFGGLDI MSDRYKLWVDTCSEIFGGLDI

MSDRYKLWVDTCSEIFGGLDI

MSDRYKLWVDTCSEIFGGLDI
Q482

PGPQRQGPPLQQRPPPQGQQH PGPQRQGPPLQQRPPPQGQQH PGPQRQGPPLQQRPPPQGQQH PGPQRQGPPLQQRPPPQGQQH PQRQGPPLQQRPPPQGQQHLS

\section{Figure 1}

Two Asian patients with maternal inherited SYN1 mutations. The above two figures (a \& b) show the segregation of the SYN1 variants in the two families. Figure $1 \mathrm{a}$ for pedigree $\mathrm{A}$ and figure $1 \mathrm{~b}$ for pedigree $\mathrm{B}: \odot$, female carrier; $\mathbf{\square}$, affected male; arrow, the proband; $\triangle$, induced abortion and triangle with single diagonal bar, spontaneous abortion. The middle two figures (c \& d) show electropherograms of SYN1 genomic sequences of affected males (upper panel), probands' father (middle panel), and probands' mother (bottom panel). (e) The alignment of the Synl protein sequence across species. The mutated amino acids are marked in red color and they lay in conserved positions as indicated.

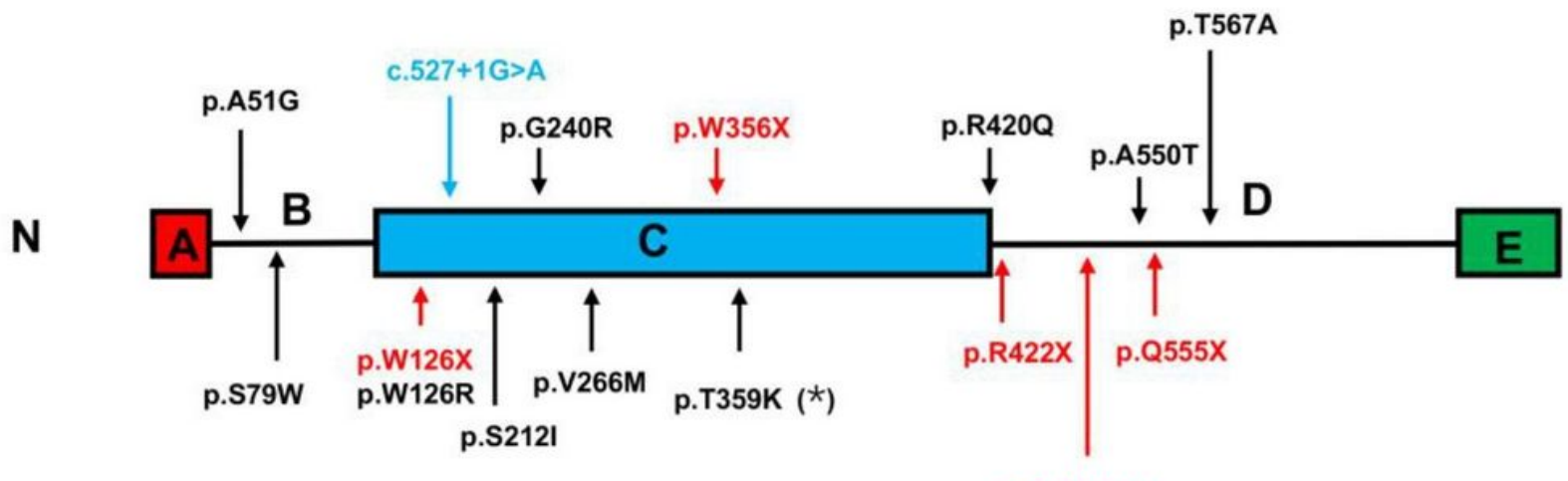

C

p.Q482X(*)

\section{Figure 2}

SYN1 protein diagram and the distribution of the mutations. The SYN1 protein consists of five domains (A-E domain). The mutations identified in previous studies and this study (marked as asterisk) are indicated with different colors denoting different mutation types, including 10 missense mutations (in black color), 5 truncation mutations (in red color), and 1 splicing mutation (in blue color). 